\title{
A Review of Environmental Implications of Dredging Activities
}

\author{
Igwe, P.U.; Ugovwarhe, O.E.P.; Ejiofor, C.C.; Menkiti, H.E.; Okonkwo, C.S.
}

Department of Environmental Management, Chukwuemeka Odumegwu Ojukwu University, P.M.B. 02, Uli, Anambra State, Nigeria

\begin{abstract}
Dredging is a global anthropogenic excavation activity of removing sediments from water bodies and depositing it elsewhere. It is a mixed blessing as it has both beneficial and adverse impacts. This paper is on a review of environmental implications of dredging. The objective of the paper is to review previous works by researchers on the environmental consequences of dredging. The method used is a review of academic/journal articles, internet materials, conference I workshop papers, textbooks, bulletins and publicly available materials on dredging activities. The results of the study revealed that previous authors whose works were reviewed have a convergent view that apart from the beneficial impacts of dredging (e.g. keeping waterways navigable, flood and storm protection and provision of materials for road construction and building), it has lots of adverse environmental impacts, including environmental pollution, erosion, widespread hydrological changes, reduction in the population of aquatic lives like destruction of fish spawning grounds and benthic organisms and resuspension of particulate matter column that has elevated levels of lead, copper, zinc and nickel in Phytoplankton. Recommendations of the study include: (1) establishment of environmental legislations and regulations for dredging operation; (2) use of green technology in dredging activities to minimize suspension of sediments and contamination/pollution of dredging environments; and (3) creation of awareness among dredging contractors, regulators and marine communities where dredging take place on the economic and ecological values of the marine ecosystems that are usually very sensitive, fragile and productive.
\end{abstract}

Keywords - Dredging, Environmental Implications, Marine Ecosystems, Review Sediment, Sustainable Development.

\section{INTRODUCTION}

Dredging is a worldwide excavation activity that involves removing sediment from a sea, river, or lakebed and depositing it at a new location ( Brunn, Gayes, and Eiser, 2005; Thomsen, McCully, Wood, Pace and White, 2009). They further reported that uses of dredged materials are vast and include construction of ports, waterways, dykes, and other marine infrastructure, land reclamation, flood and storm protection, extraction of the construction industry (e.g for road construction and buildings) and in environmental remediation of contaminated sediments. International Association of Dredging Company (IADC) (2012) opined that population growth and increasing number and size of infrastructure projects mean that demand for dredging, volume of aggregate, and turnover will most likely increase. Since dredging impacts the marine environment, sustainable management of the activity is required, based on in-depth understanding of how dredging affects marine habitats and associated fauna and flora (Thrush and Dayton, 2002; David, Hitchcock and Bell ,2004; Erftemeijer and Lewis, 2006).

Globally, dredging activities certainly affect the global economy and in fact still plays a huge role in global trade (Bob, 2015). IADC (2012), reported an estimated 11.68 billion of dredging work. In Nigeria, dredging activities are a major environmental problem (Abubaker, Alzubi and Alzyond, 2011). They further noted that mining industries and dredging practices in particular are vastly known for their hazardous working condition and the unstable nature of the earth-crust which minerals are extracted is causing threat to life and properties of the society. According to Robbins (2006), dredging is an excavation activity of operations usually carried out at least partly under water, in shallow seas or fresh water areas with purpose of gathering up bottom sediments and disposing them at a different location. He further asserted that dredging helps to keep waterway navigable, and also a way of replenishing sand on some public beaches, where sand has been lost because of coastal erosion.

Walker, Hillman, Kendrick and Lavery (2001) defined dredging as an activity that is done or carried out using a device, machine or vessel that is used to excavate and remove materials from the bottom of a body of water, for example, a scoop is attached to the rope or pole by which a man can draw sediments up from the bottom of a pond, or river. In the view of Watson, Revenga and Kura (2006), dredging involves the excavation and relocation of sediments from lakes, rivers, estuaries or seabed and is a critical component of most major marine infrastructure development along the coast. Despite the necessity of 
dredging for industrial development, its potential impacts on the environment are particular concern as multiple potential stressors associated with dredging activities are sediment stress (suspended and deposited), release of toxic contaminants, hydraulic entrainment and noise pollution (Reine, Clerk and Dickerson, 2014; McCook, Schaffelke, Erftemeijer and Warne, 2015). The process of dredging creates spoils (excess materials), which are carried away from the dredging area; dredging can create disturbance in aquatic ecosystem after with adverse impacts (Bertha, 2009). He further claimed that dredging can create much effect on land. Dredging has a number of undesirable geomorphic consequences, showing the vertical incision and bank destabilization can occur from dredging activities (Mmom and Chukwu-Okeah, 2012).

\subsection{Statement of the Problem}

Dredging has created a lot of problems and these include change in the aquatic ecosystem, environmental pollution, flooding of coastal land and erosion, infrastructural damage, flooding of coastal land and reduction in the population of aquatic lives useful to man (Fortes, 2001). He further reported that dredging activities often disturb sediments reducing visibility and smothering reef organisms. Ohimain and Van Mensvoort (2004) asserted that dredging has been associated with widespread hydrological changes as it may disrupt the dynamic interrelationship between environmental components and socio-economic functions of these coastal areas, thus creating an imbalance in the ecosystem. The extent at which dredging occurs in rivers, lakes, ponds, coastal regions is becoming a treat (IADC) (2012). Environmental Protection Agency (EPA) (2013) reported that dredging activities has potential to change the environment, as well as toxicant, the nutrients (elements), particularly nitrogen and phosphorus which control the rate of marine plant growth, can be released from sediments during dredging with a risk of triggering algae blooms. Dredging activities potentially affect not only the site itself, but also surrounding areas, through a large number of impact factors such as turbidity, sedimentation, resuspension and release of contaminants effects can be immediate or develop over a longer time frame and they may be temporary or permanent in nature (Wolanski and Gibbs, 2004).

\subsection{Objective of the Study}

The objective of this paper is to review environmental implications of dredging activities.

\section{CONCEPTUAL FRAMEWORK: SUSTAINABLE DEVELOPMENT}

This paper adopts the concept of sustainable development as its framework. The World Conference on Environment and Development (WCED) (1987) defined sustainable development as the development that meets the needs of the present without compromising the ability of future generations to meet their own needs.

Morelli and Greenwood (2010) claimed that sustainable development is meeting the resource and service needs for current and future generations without compromising the health of the ecosystems that provide them and more specifically as a condition of balance, residence and interconnection that allows human society to satisfy its needs while neither exceeding the capacity of its supporting ecosystems to continue to regenerate the services necessary to meet those needs by our actions diminishing biological diversity.

This study is focused on a review of the environmental implications of dredging so as to build in sustainability into the management of the phenomenon.

\section{METHOD}

This research made use of a review of academic articles, journals, internet materials, textbooks, conference papers and publicly available materials on dredging activities. The researchers assembled thirty of these materials for this research, but summarized the characteristics of 10 deemed more relevant to environmental implications of dredging for the review. This enabled the researchers to make a synthesis of various researchers' views on implications of dredging activities.

\section{REVIEW OF RELATED LITERATURE}

Watson, Ravenga and Kura (2006) conducted a study on Trawling and Dredging in Western Australia and asserted that dredging involves the excavation and relocation of sediment from lakes, rivers, estuaries or seabed and is a critical component of most major marine infrastructure development along the coast. Hitchcock and Bell (2004) carried out a study on marine aggregate dredging in Florida and reported that sediment plumes cannot be under estimated as it is a phenomenon that has the capacity to extend the footprint of impact beyond the limits of the dredging activity itself. Copper, Curtis, Hussain, Barrio Fajon, Defew and Nye (2011) studied implications of dredging in United Kingdom and claimed that changes in sediment composition can have implications for residents and recolonizing fauna, resulting in the establishment of fauna community that differs from the assemblage present before the dredging. They also asserted that marine aggregate dredging is to identify those locations where it is more and less important to try to preserve sediment particle size composition, and to determine whether there is a rational scientific justification for the active restoration of sediment particle size composition at site of former marine aggregate dredging. 
In their study on impact of dredging seagrassses in the Netherlands, Erftemeijer and Lewis (2006) reported that dredging and disposal of dredged materials can lead a temporary decrease in water transparency, increased concentrations of suspended matter and increased rates of sedimentation. They also opined that impacts can be significant when dredging or disposal is done in the vicinity of sensitive marine environments, such as coral reefs and sea grass bed. Cooper, Boyd, Eggleton, Limpenny, Rees and Vanstaen (2007), in their study on marine aggregate dredging in England, and asserted that deposition of sediment from plums created during dredging operations will likely inhibit recovery of benthic communities. Wilber and Clarke (2001) did a research on suspended sediment in Charleston and noted that dredging released nutrients that led to depletion of oxygen from high phytoplankton production. Michael, Woodley, Todd and David (2015) conducted a study on suspended sediment in Vicksburg and claimed that river channel maintenance relies on frequent dredging to keep the water ways navigable. Nayar, Miller, Hunt and Goh (2007) were of the view that dredging of channel and excavation of the banks exposed the underlying layer of historically contaminated sediments, compromising partially decomposed organic matter from dredging activities, resuspension of sediment partially accounted for higher concentrations of organic carbon in water column, in their study on impacts of dredging in Singapore. A research by Nayar, Goh and Chou (2004) on heavy metals from dredging in Singapore revealed that dredging operations potentially released toxins into the marine environment. They further claimed that in Zeebrugge and Singapore dredging, operations led to resuspension of particulate matter column that has elevated levels of lead, copper, zinc and nickel recorded in phytoplankton.
Walker, Hillman, Kendrick and Lavery (2001) researched on ecological significance of dredging in Western Australia and asserted that dredging in shallow nearshore waters associated with significant conservation values, adverse effects on marine habitats due to direct seabed disturbance and indirect effects could offset shipping movements and seabed shoreline stability. A research by Desprez (2000) on impact of marine aggregate dredging in France indicated that extraction of marine aggregate has its impact on the seabed as dredging activity has conventionally targeted bottom substrate associated with benthic fauna. Mmom and Chukwu-Okeah (2012), in their study on sand dredging in Calabar, opined that increasing anthropogenic disturbances have imposed considerable impacts on river channel. They further reported that high dredging activities had resulted to serious incision of the river channel deepening the river bed and increasing velocity of flow. Rinaldi, Wyzga and Surian (2005) conducted a study on sediment mining in Italy and claimed that channel incision of alluvial river as a result of sediment depletion arising from dredging had series of detrimental effects on the river channel, including ground water table lowering, flood flow increase, the destabilization of infrastructures, sea water encroachment in the area. Michael et al (2015) carried out a research on potential dredging impact in Vicksburg and reported that dredging is a complex activity, and its impact on aquatic ecosystems is poorly understood, over long-time scales. Muyideen, Abiodun and Ismaila (2013), in their study on impacts of dredging in Awoyaya Lagos, claimed that dredging activity pollutes the environment and the water source of the area, thereby endangering the life of people and aquatic animal in the area.

Table.1: Summary of Characteristic of some Studies on Environmental Implications of Dredging Activities.

\begin{tabular}{|c|c|c|c|c|c|c|}
\hline$S / N$ & Author(s) & Topic of Research & $\operatorname{Method}(s)$ & Results & Recommendations & Conclusion \\
\hline 1 & $\begin{array}{l}\text { Cooper, Curtis, } \\
\text { Hussian, Barrio } \\
\text { frojan, Defew, } \\
\text { Nye and } \\
\text { Paterson } \\
(2011) .\end{array}$ & $\begin{array}{l}\text { Implications of } \\
\text { Dredging Induced } \\
\text { Changes in Sediment } \\
\text { Particle Size } \\
\text { Composition for the } \\
\text { structure and } \\
\text { function of marine } \\
\text { benthic macro-faunal } \\
\text { communities. }\end{array}$ & $\begin{array}{l}\text {-Physical } \\
\text { Observation } \\
\text {-Laboratory } \\
\text { analysis }\end{array}$ & $\begin{array}{l}\text { The result } \\
\text { suggested that } \\
\text { the presence of } \\
\text { gravel has an } \\
\text { important role in } \\
\text { the negative } \\
\text { correlation in } \\
\text { sediment } \\
\text { composition of } \\
\text { natural physical } \\
\text { disturbance. }\end{array}$ & $\begin{array}{l}\text { License } \\
\text { enforcement } \\
\text { should be put in } \\
\text { place regarding } \\
\text { changes in } \\
\text { sediment } \\
\text { composition. }\end{array}$ & $\begin{array}{l}\text { Changes in } \\
\text { sediment } \\
\text { composition in } \\
\text { the area are likely } \\
\text { to have a reduced } \\
\text { impact on the } \\
\text { overall faunal } \\
\text { assemblage, } \\
\text { possibility and } \\
\text { measurable in } \\
\text { sediment } \\
\text { composition. }\end{array}$ \\
\hline 2 & $\begin{array}{l}\text { Copper, Boyd, } \\
\text { Eggleton, } \\
\text { Limpenny, } \\
\text { Rees and } \\
\text { Vanstae (2007). }\end{array}$ & $\begin{array}{l}\text { Recovery of the } \\
\text { Seabed Following } \\
\text { Marine Aggregate } \\
\text { Dredging on the } \\
\text { Hastings Shingle } \\
\text { Bank Off the }\end{array}$ & $\begin{array}{l}\text {-Site } \\
\text { Observation } \\
\text {-Laboratory } \\
\text { Analysis. }\end{array}$ & $\begin{array}{l}\text { The result from } \\
\text { both sites } \\
\text { provides a useful } \\
\text { in-sight of the } \\
\text { processes leading } \\
\text { to recovery of the }\end{array}$ & $\begin{array}{l}\text { Caution in assuring } \\
\text { recovery figure } \\
\text { should be } \\
\text { applicable to } \\
\text { intensively } \\
\text { dredged areas. }\end{array}$ & $\begin{array}{l}\text { A comparison of } \\
\text { recent and } \\
\text { historic dredged } \\
\text { track features } \\
\text { provided } \\
\text { evidence of track }\end{array}$ \\
\hline
\end{tabular}




\begin{tabular}{|c|c|c|c|c|c|c|}
\hline$S / N$ & Author(s) & Topic of Research & $\operatorname{Method}(s)$ & Results & Recommendations & Conclusion \\
\hline & & $\begin{array}{l}\text { South-east Coast of } \\
\text { England. }\end{array}$ & & $\begin{array}{l}\text { seabed marine } \\
\text { aggregate } \\
\text { dredging at the } \\
\text { site. }\end{array}$ & & erosion. \\
\hline 3 & $\begin{array}{l}\text { David, } \\
\text { Hitchcock and } \\
\text { Bell (2004). }\end{array}$ & $\begin{array}{l}\text { Physical Impacts of } \\
\text { Marine Aggregate } \\
\text { Dredging on Seabed, } \\
\text { Resources in Coastal } \\
\text { Deposits. }\end{array}$ & $\begin{array}{l}\text {-Survey } \\
\text { Strategy }\end{array}$ & $\begin{array}{l}\text { The result } \\
\text { reported that the } \\
\text { geological } \\
\text { conditions are } \\
\text { more likely to } \\
\text { result from } \\
\text { dredging } \\
\text { disturbance. }\end{array}$ & $\begin{array}{l}\text { Deep-water } \\
\text { extensive } \\
\text { operations with } \\
\text { screening of } \\
\text { cargoes should be } \\
\text { avoided. }\end{array}$ & $\begin{array}{l}\text { It is clear that } \\
\text { development of } \\
\text { linear down tide } \\
\text { extension near } \\
\text { bed sediment } \\
\text { plume provides a } \\
\text { mechanism for } \\
\text { potential impacts } \\
\text { in areas where } \\
\text { screening cargoes } \\
\text { takes place. }\end{array}$ \\
\hline 4 & $\begin{array}{l}\text { Muyidean, } \\
\text { Abiodun, and } \\
\text { Ismaila (2013). }\end{array}$ & $\begin{array}{l}\text { Environmental } \\
\text { Impacts of Dredging } \\
\text { in Awoyaya, Lagos } \\
\text { State, Nigeria. }\end{array}$ & $\begin{array}{l}\text {-Laboratory } \\
\text { analysis } \\
\text {-Physical } \\
\text { Observation. }\end{array}$ & $\begin{array}{l}\text { Water is acidic } \\
\text { and soil has a } \\
\text { very } \\
\text { percentage high } \\
\text { silica. }\end{array}$ & $\begin{array}{lr}\text { Disturbance } \\
\text { arising rom } \\
\text { dredging operation } \\
\text { should r be } \\
\text { controlled r and } \\
\text { standards should } \\
\text { be set to decrease } \\
\text { disturbance r of } \\
\text { dredging } \\
\text { operation. }\end{array}$ & $\begin{array}{l}\text { The analysis } \\
\text { carried out shows } \\
\text { that dredging in } \\
\text { Awoyaya has } \\
\text { little impact on } \\
\text { water and soil in } \\
\text { the dredging area. }\end{array}$ \\
\hline 5 & $\begin{array}{l}\text { Mmon, and } \\
\text { Chukwu-okeah } \\
(2011) .\end{array}$ & $\begin{array}{l}\text { Sand Dredging and } \\
\text { River Morphology } \\
\text { Change Along Parts } \\
\text { of New Calabar river } \\
\text { in Akpor Area of } \\
\text { Rivers State, Nigeria } \\
\text { and its implication } \\
\text { for Biological } \\
\text { resources } \\
\text { conservation. }\end{array}$ & $\begin{array}{l}\text {-Laboratory } \\
\text { Analysis } \\
\text {-Physical } \\
\text { Observation. }\end{array}$ & $\begin{array}{l}\text { The high } \\
\text { dredging } \\
\text { activities in the } \\
\text { area has resulted } \\
\text { to serious } \\
\text { incision of the } \\
\text { river channel } \\
\text { thereby } \\
\text { deepening the } \\
\text { river bed and } \\
\text { increasing the } \\
\text { velocity of flow. }\end{array}$ & $\begin{array}{l}\text { Proper checking of } \\
\text { dredging activities } \\
\text { along the river } \\
\text { course to protect } \\
\text { the environment } \\
\text { and biodiversity } \\
\text { from net loss or } \\
\text { decimation. }\end{array}$ & $\begin{array}{l}\text { The dramatic } \\
\text { river bed } \\
\text { down-cutting as a } \\
\text { result of sediment } \\
\text { depletion has } \\
\text { important } \\
\text { implication for } \\
\text { river } \\
\text { management of } \\
\text { the rivers. }\end{array}$ \\
\hline 6 & $\begin{array}{l}\text { Nayar, Miller, } \\
\text { Hunt, Goh, and } \\
\text { Chou (2007). }\end{array}$ & $\begin{array}{l}\text { Environmental } \\
\text { Effects of Dredging } \\
\text { on Nutrients, Carbon } \\
\text { and Granulometry in } \\
\text { a tropical Estuary }\end{array}$ & $\begin{array}{l}\text {-Laboratory } \\
\text { analysis }\end{array}$ & $\begin{array}{l}\text { The mean and } \\
\text { range for nutrient } \\
\text { concentrations } \\
\text { showed } \\
\text { relatively } \\
\text { elevated levels } \\
\text { post dredging } \\
\text { were positively } \\
\text { and significantly } \\
\text { correlated with } \\
\text { sand fraction. }\end{array}$ & $\begin{array}{l}\text { Monitoring study } \\
\text { should be used for } \\
\text { effective } \\
\text { management } \\
\text { strategy to protect } \\
\text { the environment. }\end{array}$ & $\begin{array}{l}\text { The most obvious } \\
\text { impact of the } \\
\text { anthropogenic } \\
\text { activities in } \\
\text { tropical estuary } \\
\text { was the } \\
\text { bioavailability } \\
\text { and dispersion of } \\
\text { nutrients. }\end{array}$ \\
\hline 7 & $\begin{array}{ll}\text { Nayar, } & \text { Goh, } \\
\text { and } & \text { Chou } \\
(2004) . & \end{array}$ & $\begin{array}{l}\text { Environmental } \\
\text { Impact of Heavy } \\
\text { Metals from Dredged } \\
\text { and Re-Suspended } \\
\text { Sediments on } \\
\text { Phytoplankton and } \\
\text { Bacteria Assessed in } \\
\text { In-situ Mesocosms. }\end{array}$ & $\begin{array}{l}\text {-Site } \\
\text { Observation } \\
\text {-Laboratory } \\
\text { analysis }\end{array}$ & $\begin{array}{l}\text { The study } \\
\text { revealed some } \\
\text { high } \\
\text { concentrations of } \\
\text { heavy metals in } \\
\text { suspended } \\
\text { particulates and } \\
\text { sediments in } \\
\text { water level. }\end{array}$ & $\begin{array}{l}\text { Mesocosms should } \\
\text { be used for testing } \\
\text { since it is very } \\
\text { sensitive and } \\
\text { reliable for modest } \\
\text { investment. }\end{array}$ & $\begin{array}{l}\text { Phytoplankton } \\
\text { was inhibited, } \\
\text { concentration of } \\
\text { heavy metals that } \\
\text { were available } \\
\text { from sediment } \\
\text { re-suspended by } \\
\text { dredging. }\end{array}$ \\
\hline 8 & $\begin{array}{l}\text { Walker, } \\
\text { Hillman, }\end{array}$ & $\begin{array}{l}\text { Ecological } \\
\text { Significance of Sea }\end{array}$ & $\begin{array}{l}\text {-Laboratory } \\
\text { analysis }\end{array}$ & $\begin{array}{ll}\begin{array}{l}\text { Differences } \\
\text { between }\end{array} \text { sea } \\
\end{array}$ & $\begin{array}{l}\text { Parameters should } \\
\text { be represented by a }\end{array}$ & $\begin{array}{l}\text { The synthesis of } \\
\text { these }\end{array}$ \\
\hline
\end{tabular}




\begin{tabular}{|c|c|c|c|c|c|c|}
\hline$S / N$ & Author(s) & Topic of Research & $\operatorname{Method}(s)$ & Results & Recommendations & Conclusion \\
\hline & $\begin{array}{l}\text { Kendrick, and } \\
\text { Lavery (2001). }\end{array}$ & $\begin{array}{l}\text { grasses: Assessment } \\
\text { or Management of } \\
\text { Environmental in } \\
\text { Western Australia. }\end{array}$ & $\begin{array}{l}\text {-Physical } \\
\text { observation }\end{array}$ & $\begin{array}{l}\text { grass habitats are } \\
\text { less pronounced } \\
\text { in terms of } \\
\text { species presents. }\end{array}$ & $\begin{array}{l}\text { probability } \\
\text { distribution with } \\
\text { values around the } \\
\text { mean valve. }\end{array}$ & $\begin{array}{l}\text { muilt-disciplinary } \\
\text { studies has } \\
\text { required the } \\
\text { development of } \\
\text { new techniques to } \\
\text { deal with } \\
\text { stochastic } \\
\text { processes. }\end{array}$ \\
\hline 9 & $\begin{array}{l}\text { Watson, } \\
\text { Revenga and } \\
\text { Kura (2006). }\end{array}$ & $\begin{array}{l}\text { Fishing Gear } \\
\text { associated with } \\
\text { Global II. Trends in } \\
\text { Trawling and } \\
\text { Dredging. }\end{array}$ & $\begin{array}{l}\text { Literature } \\
\text { review }\end{array}$ & $\begin{array}{l}\text { Composition of } \\
\text { trawl and } \\
\text { dredged catch is } \\
\text { quite diverse. }\end{array}$ & $\begin{array}{l}\text { Analysis should be } \\
\text { extremely valuable } \\
\text { to inform policy } \\
\text { development and } \\
\text { to help develop } \\
\text { future } \\
\text { management } \\
\text { options. }\end{array}$ & $\begin{array}{l}\text { Dredging usually } \\
\text { associated with } \\
\text { the catch of } \\
\text { bivalves often } \\
\text { peaked later than } \\
\text { trawling had } \\
\text { decline in most } \\
\text { areas. }\end{array}$ \\
\hline
\end{tabular}

Source: Researchers' design, 2017.

\section{RESULTS AND DISCUSSION}

Dredging activities have a lot of environmental implications. From Table 1, Nayar, Goh and Chou (2004) and Nayar et al (2007) are of the convergent view that resuspension of sediment partially accounted for higher concentrations of organic carbon, as dredging activity potentially release toxins into the marine environment. Mmom and Chukwu-okeah (2012) and Rinaldi et al (2005) were of the view that dredging activities have resulted to serious incision of river channel including ground water table lowering, flood flow increase, destabilization of infrastructures and sea water encroachment in the area. Muyideenn et al (2013) asserted that dredging activity pollutes the environment and water source of the area as well endangering the life of people and aquatic animal in the area. Michael et al (2015) reported that dredging is a complex activity which has impact on aquatic ecosystem over long-time scales. They were of the divergent view that dredging is done to maintain water ways navigable.

David, Hitchcock and Bell (2004) reported that dredging disturbance will likely result to geological conditions. Mmom and Chukwu-Okeah (2011) deduced that high dredging activities have resulted to serious incision of river channel, deepening the river bed and increasing the velocity of flow. Generally, dredging activities have a lot of environmental implications that tend to pollute the environment as well as endangering life of people and aquatic animals. For example, in Zeebrugge and Singapore dredging operations led to resuspension of particulate matter column in phytoplankton (Nayar, Goh and Chou, 2004).

\section{RECOMMENDATIONS}

From the results of this study, the following recommendations are hereby made:

1. Environmental legislations and regulations should be established to monitor dredging operations to reduce adverse environmental impacts.

2. The use of suitable dredging equipment should be encouraged in other to minimize suspension of sediments and contaminants at dredging sites.

3. Efforts should be made to create awareness among dredging contractors and regulatory bodies on the economic and ecological values of the marine ecosystem which are usually very sensitive, fragile and productive.

4. Disturbance arising from dredging operation should be controlled and standard should be set to decrease disturbance of dredging operations.

\section{CONCLUSION}

This paper discussed environmental implications of dredging activities through a review of works of pervious authors. Generally, the authors agreed that dredging is the excavation and relocation of sediment from river, lakes, estuaries and seabed. Dredging activities potentially because disturbance to aquatic ecosystem, changes in topography by creation of spoils, short term increase in turbidity which can affect aquatic species metabolism, environmental pollution and flooding of coastal areas and erosion. This study therefore, concludes that although dredging is beneficial in socio-economic terms, its adverse environmental consequences call for proper management to avoid a situation where they undermine the positive impacts.

\section{ACKNOWLEDGEMENT}

We appreciate the grace and empowerment of God Almighty who has been our source of strength from 
beginning to completion of this work. We also commend the effort of the relations, friends and well- wishers of the authors who contributed both financially and otherwise for making this review a success. Our gratitude extends to the Vice chancellor and the entire stakeholders of Chukwuemeka Odumegwu Ojukwu University, Uli, Anambra State, Nigeria for providing a platform for the study of Environmental Management. To all the lecturers, head of department and dean of the Environmental Sciences, we appreciate their collective efforts in making sure that the goal of environmental management is achieved in the institution. We are highly indebted to the chief author, Mr. Igwe, P.U. for his tireless effort towards an extensive research on the materials used for the review. We cannot fail to commend and appreciate the works of various authors used for the review. Finally, we thank the entire students of Environmental Management especially her final year students for their support throughout the review.

\section{REFERENCES}

[1] Abubaker, S., Alzubi, J., Alzubi, Y., and Alzyond, A. (2011). Potato (Solanum tuberosum L.). Production under Phosphate-mining Wastewater in Jordan. Journal of Agronomy, 10: 128-131.

[2] Bertha, J. (2009). World of Boats. Eyemouth, Scotland: Eyemouth Marine Centre

[3] Bob, W. (2015). Dredging Impact on the Global Economy. Mining World Magazine.

[4] Brunn, P., Gayes, P. T., Schwab, W.C., and Eiser, W.C. (2005). Dredging and Offshore Transport of Materials. Journal of Coastal Research, 2:453-525.

[5] Cooper, K.M., Boyd, S., Eggleton, J., Limpenny, D., Rees, H., and Vanstaen, K (2007). Recovery of the Seabed Following Marine Aggregate Dredging on the Hastings Shingle Bank off the Southeast Coast of England. Estuaries, Coastal and Shelf Science, 75:547-558.

[6] Copper, K.M., Curtis, M., Hussain, W. M.R., Barrio Frojan, C.R.S., Defew, E.C., Nye, V., and Paterson, D.M. (2011). Implication of Dredging Induced Changes in Sediment Particle Size Composition for the Structure and Function of Marine Benthic Macrofaunal Communities. Marine Pollution Bulletin, 62: 2089-. 2094.

[7] David, R., Hitchcock,D.R., and Bell, S. (2004). Physical Impact of Marine Aggregate Dredging on Seabed Resources in Coastal Deposits. Journal of Coastal Research, 20:101-114.

[8] Desprez, M. (2000). Physical and Biological Impact of Marine Aggregate Extraction Along the French Coast of the Eastern English Channel. ICES Journal of Marine Science, 57: 1428 - 1438.
[9] Environmental Protection Agency (EPA) (2009). Albany Port Extension Proposal. Public Environmental Protection Agency,on Behalf of the Albany Port Authority (APA), 5p.

[10] Erftemeijer, P.L.A., and Lewis, R.R.R. (2006). Environmental Impact of Dredging on Seagrasses: A Review.Marine Pollution Bulletin, 52:1553-1572.

[11]Fortes,M.D.(2001). The Effects of Siltation on Tropical Coastal Ecosystem. In Wolanski Oceanographic Processes of Coral Reefs: Physical and Biological Link in the Great Barrier Reef, CRC Press, Boca Raton, pp 93-112.

[12] International Association of Dredging Companies (IADC) (2012). Dredging in Figures. International Association of Dredging Companies.p.9.

[13] McCook, I.J., Schaffelke, B., Apte, S.C., Brinkman, R., Brodie, J., Erftemeijer, P., and Warne, M.S.J. (2015). Synthesis of Current Knowledge of the Biophysical Impacts of Dredging and Disposal on the Great Barrier Reef: Report of an Independent Panel of Experts. Great Barrier Reef Marine Park Authority.

[14] Michael, E.K., Woodley, C.M., Todd, M.S., and David, L.S. (2015). A Review of the Potential Effects of Suspended Sediment on Fishes: Potential Dredging Related Physiological, Behavioral and Transgenerational Implications. Environmental Systems and Decisions, 35:334- 350.

[15]Mmom, P.C., and Chukwu-Okeah, G.O. (2012). Sand Dredging and River Morphology Change Along Ports of New Calabar River in Akpor Area of Rivers State Nigeria and its Implications for Biological Resources Conservation Research. Journal of Environmental and Earth Sciences, 4:82-87.

[16]Morelli,J., and Greenwood.(2011). Environmental Sustainability and Professional Responsibility. Seventh Environmental Management Leadership Symposium, Rochester New York, pp. 22-24.

[17] Muyideen, A.S., Abiodun, I.L., and Ismaila, A.O. (2013). Environmental Impact of Dredging in Awoyaya, Lagos State, Nigeria. Civil and Environmental Research, 3:115-120.

[18]Nayar, S., Goh, B. P. L., and Chou, L.M. (2007). Environmental Effects of Dredging of Sediments Nutrients, Carbon and Granulometry in a Tropical Estuary. Environmental Monitoring Assess, 127: $1-13$.

[19]Nayar, S., Goh, B.P.L., and Chou, L.M. (2004). Environmental Impact of Heavy Metals from Dredged and Resuspended Sediments on Phytoplankton and Bacteria Assessed in In-situ Mesocosms. Ecotoxicology and Environmental 
Safety, 59: 349- 369.

[20] Ohiman,E.I., and Van Mensvoort,M.E.F. (2003),.Environmental Impacts of Abandoned Dredged Soil and Sediments: Available Options for their handling, Restoration and Rehabilitation. Journal of Soil and Sediments, 4: 59-65.

[21] Reine, K. J., Clarke,D.G., and Dickerson, C. (2014). Characteristics of Underwater Sounds Produced by Hydraulic and Mechanical Dredging Operations. Journal of the Acoustical Society of America, 135: 3280 - 3294.

[22] Rinaldi, M., Wyzga, B., and Surian, N. (2005). Sediment Mining in Alluvial Channels. Physical Effects and Management Perspectives. River Research and Applications, 21:805-825.

[23] Robbins, R. (2006). USAP Surface- Supplied Diving. Proceedings of Advanced Scientific Diving Workshop. Washington, DC: Smithsonian Institution.

[24] Thomsen, F., McCully, S., Wood, D., Pace, F., and White, P. (2009). A Generic Investigation into Noise profiles of Marine Dredging in Relation to the Acoustic Sensitivity of Marine Fauna in United Kingdom Waters with Particular Emphasis on Aggregate Dredging. Phase 1 Scoping and Review of Ice Issues, p.21.

[25] Thrush, S. F., and Dayton, P. K. (2002). Disturbance to Marine Benthic Habitats by Trawling and Dredging: Implications for Marine Biodiversity. Annual Review of Ecology, Evaluation and Systematics, 33: 449-473.

[26] Walker, D.I., Hillman, K.A., Kendrick, G.A., and Lavery, P. (2001). Ecological Significance of Seagrasses. Assessment for Management of Environmental Impact in Western Australia. Ecological Engineering, 16:323-330.

[27] Watson, R., Revenga, C., and Kura, Y. (2006). Fishing Gear Associated with Global Marine Catches: Trends in Trawling and Dredging. Fisheries Research, 79:103-111.

[28] Wilber, D.H., and Clarke, D.G. (2001). Biological Effects of Suspended Sediments: A Review of Suspended Sediment Impact on Fish and Shellfish with Relation to Dredging Activities in Estuaries. North American Journal Fisheries Management, 21:855-875.

[29] Wolanski, E., and Gibbs, R. (2004). Resuspension and Clearing of Dredging Spoils after Dredging. Cleveland Bay. Australian. Water Environment Research, 64:910-914.

[30] World Conference on Environment and Development (WCED) (1987). Our Common Future Oxford University Press. 